\title{
Contexts of qualitative research in health
}

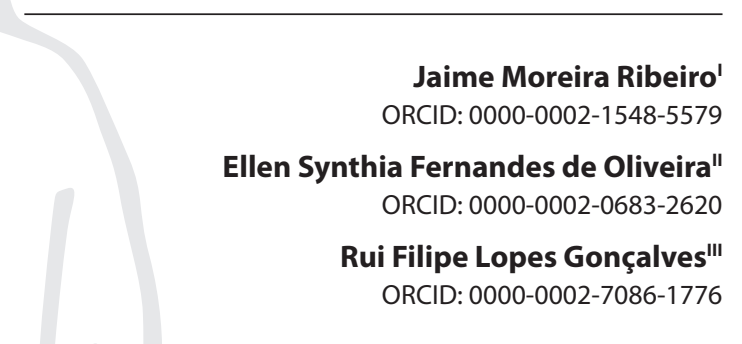

'Universidade de Aveiro \& Center for Innovative Care and Health Technology - CiTheCare, Centro de Investigação em Didática e Tecnologia na Formação de Formadores, Politécnico de Leiria. Leiria, Portugal.

"Universidade Federal de Goiás, Brazil. "'Unidade de Investigação em Ciências da Saúde: Enfermagem, Escola Superior de Enfermagem de Coimbra. Coimbra, Portugal.

How to cite this article: Ribeiro JM, Oliveira ESF, Gonçalves RFL. Contexts of qualitative research in health. Rev Bras Enferm. 2021;74(1):e740101. doi: http://dx.doi.org/10.1590/0034-7167.2021740101
When the theme is the qualitative approach to research, the famous clichés emerge: depth and not generalization are intended, it is a particularistic investigation. But what is this particularistic?

At first, qualitative research can be understood as one that produces findings that do not come from any quantification procedures or forms. Through this type of investigation, it is possible to understand the symbolic and particular universe of experiences, behaviors, emotions and feelings experienced, or even to understand the organizational functioning, social movements, cultural phenomena and interactions between people, their social groups and institutions ${ }^{(1-2)}$.

Consideration is given to the natural contexts in which individuals or groups function to provide a deep understanding of real-world problems. It is particular and specific because it considers the phenomenon studied in its context within the spatial, temporal, socioeconomic, political and any other dimensions that condition population's perspectives, such as living in pandemic times with restrictions on freedom. Perspectives that vary according to the context that is experienced, with the social group to which it belongs, with extemporaneous phenomena, observing, for instance, sudden changes due to social contagion.

In the view of qualitative research, we believe in the uniqueness of the phenomena, so the generalization is opposed to the very intricate transferability, which can only occur in the face of similarities of contexts, and even this can always be contested.

In other words, the inseparability of the phenomena of their context is recognized as it is not possible to analyze individuals' perceptions and meanings, silencing the context ${ }^{(3)}$. The context must be seen as something fluid, as a non-static set of influential circumstances ${ }^{(4)}$, of variables that, in a cycle, reorganize themselves before the variability of the context, which in turn reacts to the variables it influences in an action-reaction-reaction sequence.

Qualitative research does not only add a set of methods to control and experimental groups, it is positioned in a different investigative paradigm. It brings new justifications for doing research, it has different beliefs and valuations about the type of data collection and its analysis. It is these fundamental assumptions that sift the ontoepistemological debate on health and social science research ${ }^{(5)}$.

We have observed a strong increase in the volume of published texts on qualitative research, more focused on the selection of techniques and implications of different conceptual structures, analysis and usability of the finding $\mathrm{s}^{(6-7)}$. The question arises: why was this investment in qualitative research in the health field previously based almost exclusively on clinical trials?

Now, we used the words of Ribeiro, Souza and $\operatorname{Costa}^{(3)}$, when they justify that this investment is due to the need to build knowledge about the main focus of health... recipients and caregivers"Undoubtedly, health belongs to people, for people and by people". Knowing the perspectives of those involved in the health-disease process, understanding the emotions and behaviors of patients, 
families and health professionals contribute to the improvement and enhancement of health care provided, fostering collaboration in health actions implemented individually and collectively ${ }^{(3)}$.

The qualitative methodology allows researchers to get into the thinking and the meanings of the phenomenon by giving subjects a voice and knowing health professionals' perceptions and feelings about the daily work at the aspects that give them pleasure or suffering. Likewise, it is essential to know the experiences of health care recipients and their families through phenomenological studies, making the data collection process interactive, which accompanies the progress of the research ${ }^{(8)}$ on, among others, perceptions and expectations of care, changes in attitude towards health-disease and perception of care receivers' own abilities in meeting their needs.
Considering the current moment of suffering and sacrifice imposed by the pandemic crisis, there is an urgent need for the emergence and development of new strategies to identify, understand and face the phenomenon ${ }^{(9)}$. Aware of the restrictions imposed on direct access to care recipients and their families, it is important to recreate the data collection methods during the research process.

The challenges are enormous for health researchers. The planetary health emergency scenario requires adjustments in the research plans design. With regard to qualitative research, adjustment goes from planning to data collection and analysis, methods, techniques, ethical framework and safety of researchers. Nevertheless, this context represents a framework of opportunities for qualitative research.

\section{REFERENCES}

1. Strauss AL, Corbin JM. Basics of qualitative research : techniques and procedures for developing grounded theory. 2nd ed. Thousand Oaks, CA: Sage Publications; 1998.

2. Minayo MCS. Pesquisa social: teoria, método e criatividade. 27th ed. Petrópolis: Vozes; 2008.

3. Ribeiro J, Souza DN, Costa AP. Qualitative research in the area of health: the whys and wherefores. Cienc Saúde Coletiva. 2016;21(8):2325. doi: 10.1590/1413-81232015218.15612016

4. Brandão C, Ribeiro J. A importância do contexto na investigação qualitativa. Rev Psicol Divers e Saúde. 2018;7(1):169-73. doi: 10.17267/2317-3394. v7i1.1897

5. Willis JW. Foundations of qualitative research: interpretive and critical approaches. Thousand Oaks, CA: Sage Publications; 2007.

6. Berg BL. Qualitative research methods for the social sciences. 7th ed. Boston: Allyn and Bacon; 2008.

7. Silverman D. Doing qualitative research: a practical handbook. 3rd ed. Thousand Oaks, CA: Sage Publications; 2009.

8. Korstjens I, Moser A. Series: Practical guidance to qualitative research. part 2: Context, research questions and designs. Eur J Gen Pract. 2017;23(1):274-9. doi: 10.1080/13814788.2017.1375090

9. Cabral Filho JE. Covid-19 Desafios e oportunidades para artigos qualitativos. Rev Bras Saúde Mater Infant. 2020;20(1):5-6. doi: 10.1590/1806-93042020000100001 